\title{
Article
}

\section{Conditional linkages between iron ore exports, foreign aid and terrorism}

\author{
Asongu, Simplice A. and Nwachukwu, Jacinta Chikaodi \\ Available at http://clok.uclan.ac.uk/24912/ \\ Asongu, Simplice A. and Nwachukwu, Jacinta Chikaodi ORCID: 0000-0003- \\ 2987-9242 (2016) Conditional linkages between iron ore exports, foreign aid \\ and terrorism. Mineral Economics, 29 (2-3). pp. 57-70.
}

It is advisable to refer to the publisher's version if you intend to cite from the work. http://dx.doi.org/10.1007/s13563-016-0088-1

For more information about UCLan's research in this area go to

http://www.uclan.ac.uk/researchgroups/ and search for <name of research Group>.

For information about Research generally at UCLan please go to http://www.uclan.ac.uk/research/

All outputs in CLoK are protected by Intellectual Property Rights law, including Copyright law. Copyright, IPR and Moral Rights for the works on this site are retained by the individual authors and/or other copyright owners. Terms and conditions for use of this material are defined in the policies page.

\section{CLoK}

Central Lancashire online Knowledge www.clok.uclan.ac.uk

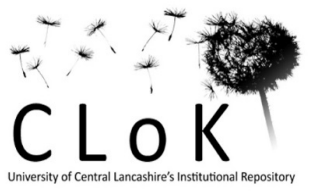




\section{A G D I Working Paper}

\section{WP/16/035}

Conditional linkages between iron ore exports, foreign aid and terrorism

Forthcoming: Mineral Economics

Simplice A. Asongu

African Governance and Development Institute,

P.O. Box 8413 Yaoundé, Cameroon.

E-mail: asongusimplice@yahoo.com /asongus@ afridev.org

\section{Jacinta C. Nwachukwu}

School of Economics, Finance and Accounting,

Faculty of Business and Law,

Coventry University

Priory Street, Coventry, CV1 5FB, UK

Email: jacinta.nwachukwu@ @ coventry.ac.uk 
Research Department

\title{
Conditional linkages between iron ore exports, foreign aid and terrorism
}

\author{
Simplice A. Asongu \& Jacinta C. Nwachukwu
}

March 2016

\begin{abstract}
We employ interactive quantile regressions to assess conditional linkages between foreign aid, iron ore exports and terrorism from a panel of 78 developing countries for the period 1984-2008. The following main findings are established. First, it is primarily in the countries with the highest level of iron ore exports that terrorism affects exports. Second, bilateral aid has an impact on iron ore exports, while the evidence for such a relationship between multilateral aid and iron ore exports is limited. Third, there is limited support for the main hypothesis motivating this line of inquiry, notably that foreign aid can be used to mitigate a potentially negative effect of terrorism on resource exports. The results suggest that bilateral aid is more relevant at mitigating the negative effects of domestic and total terrorism on iron ore exports.
\end{abstract}

JEL Classification: F40; F23; F35;Q34 ; O40

Keywords: Exports, Foreign Aid; Terrorism; Natural Resources; Development

\section{Introduction}

The world is witnessing one of the greatest challenges to peace and shared prosperity. According to the June 2015 Global Peace Index (GPI) report, the number on internally displaced persons recorded between 2008 and 2014 has been the highest since the Second World War. According to Anderson (2015), 13.4\% of Global GDP was lost in 2014 to fighting global terrorism and violence related concerns. The substantial percentage of GDP represents the combined GDP of Canada, Brazil, Spain, the United Kingdom and Germany. Consistent with Asongu and Kodila-Tedika (2015a), the report argues that terrorist activities are likely to substantially increase in the coming years because terrorist-related killings have 
soared by more than $61 \%$ in 2014 from 2008. Compared to developed countries, developing nations are more severely affected by the scourge. Moreover, the April 2015 World Bank report has revealed that many developing countries have not yet attained the Millennium Development Goals (MDGs) extreme poverty target ${ }^{1}$.

Against the above background, an evolving stream of recent literature is being increasingly devoted to assessing mechanisms by which terrorism and conflicts can been attenuated. As far as we have reviewed, the documented channels have included, the roles of: transparency (Bell et al., 2014); rule of law (Choi, 2010); learning (Brockhoff et al., 2014), especially in terms of bilingualism (Costa et al., 2008) and lifelong experiences (Asongu \& Nwachukwu, 2016); press freedom or positive use of media (Hoffman et al., 2013); best governance tools in the fight against conflicts (Asongu \& Kodila-Tedika, 2016); understanding behavioural intentions motivating terrorism (Gardner, 2007); use of military tactics and strategies (Feridun \& Shahbaz, 2010); role of global warming (Price \& Elu, 2016) and horizons for common policies in the prediction of future regional conflicts (Asongu \& Nwachukwu, 2015a) and battle against terrorism (Asongu \& Nwachukwu, 2015b).

There is another stream of the literature that has been oriented towards nexuses between political instability, terrorism, violence, crimes and macroeconomic variables. Some orientations in this interesting literature have entailed, inter alia: (i) the effect of terrorism on foreign direct investment (FDI) (Abadie \& Gardeazabal, 2008) and the role of development assistance in mitigating the potentially negative incidence of terror on FDI (Bandyopadhyay et al., 2014), contingent on domestic corruption-control levels (Efobi et al., 2015) or FDI thresholds (Asongu et al., 2015); (ii) linkages between terrorism and economic prosperity, with unidirectional (Piazza, 2006; Gaibulloev \& Sandler, 2009; Öcal \& Yildirim, 2010; Meierrieks \& Gries, 2013; Cho, 2015) and bidirectional causalities (Gries et al., 2011; Shahbaz et al., 2013; Shahzad et al., 2015); (iii) the relationship between terrorism and innovation (Koh, 2007) and (iv) the interplay of terrorism with natural resources (Humphreys, 2005). This present study is closest to the fourth (iv) and first (i) streams. In essence, this line of inquiry aims to examine the role of development assistance in mitigating the potentially negative impact of terrorism on iron ore exports. On the one hand, the positioning of the inquiry fits the first steam because it uses foreign aid as a policy variable that can dampen the

\footnotetext{
${ }^{1}$ According to the April $15^{\text {th }}$ World Bank publication on attainment of the MDG extreme poverty target (of halving poverty in 2015 from 1990), many developing countries still have a long way to go before reaching the extreme poverty target (Caulderwood, 2015; World Bank, 2015; Asongu \& Kodila-Tedika, 2015b).
} 
effect of terrorism on economic activity. On the other hand, the positioning also fits the fourth stream because it is focused on natural resources.

Consistent with the underlying trade-terrorism literature (Asongu \& Kodila-Tedika, 2015a), studies linking terrorism to trade can be classified into three principal themes, notably: the incidence of terrorism on trade; effect of illegal trade on terrorism and pitfalls in the modelling of the relationship. Four main studies are noteworthy in the first strand on the impact of terrorism on trade. They are: (1) Security measures administered in the United States after the $11^{\text {th }}$ of September 2001 terrorist attacks; essential to mitigate the unappealing effects of terrorism on world trade (Richardson, 2004), (2) Nitsch and Schumacher (2004) have examined the impact of terrorism and welfare on trade by employing an augmented gravity model on 200 nations for the period 1960-1993. Using a plethora of violence, bilateral trade and terrorism variables, the authors conclude that trade openness is negatively affected by terrorism. Moreover, doubling incidents of terrorism reduces the underlying trade by about 4 percent and (3) The connection between 'nearness to the source of terror' and negative effects on trade has been assessed by De Sousa et al. (2009a) who have concluded that there is a (i) need to carefully work-out a theory that elicits relationships between trade, transnational terror and policies of security and (ii) the importance of engaging more robust investigations on terrorism spillovers to differing definitions of neighbouring incidents and relationships. (4) De Sousa et al. (2009b) have gone further to examine the effect of international terrorism diffusion on trade and security. The motivation for the empirical underpinning is the assumption that nearness to the source of terror is negatively related to corresponding spillover effects. The core motivation underlying the line of inquiry is that measures of security which influence trade affect neighbouring countries and the source-country simultaneously. Conversely, countries that are located far-off from the source of terror could have positive rewards from trade by reaping 'trade benefits' corresponding to the 'loss of trade' by the country hosting the terror and neighbouring nations experiencing negative trade externalities from the underlying terror. Three principal results are established, notably: (i) there is a direct negative effect of transnational terrorism on trade; (ii) with terror remoteness, trade increases and (iii) a negative effect of terror indirectly affects neighbouring countries from the source-country of terror.

Concerning the second stream on the impact of illegal trade on terrorism, two main studies are noticeable in the sparse literature. These studies have been primarily focused on illicit trade. (1) Piazza (2011) has assessed the nexus between 'drugs trade' and terrorism to 
establish that cocaine production, illicit drugs and opiate considerably fuel terrorism activities (domestic and transnational). On the other hand, the eradication of illicit crops and banning of drugs have opposite effects. (2) Piazza (2012) extends the underlying study by investigating the relationship between 'opium trade' and terrorism in 34 Afghan provinces for the period 1996-2008, employing binomial regressions. The author concludes that in provinces where opium is substantially cultivated, high rates of terrorist attacks are apparent. Therefore, the direction of causality is established to be flowing from the production of opium to terrorism.

In the third strand, modelling issues have been discussed after a survey of the literature by Mirza and Verdier (2008). Four principal pitfalls are articulated from a plethora of studies on the nexus between trade and terrorism, namely the need to: (i) control for omitted variables which could most probably be linked to trade and terrorism; (ii) recognise the inter-temporal persistence of terror; (iii) distinguish between the effect of incidental country-specific incidences of terrorism from the impact of occurrences that are oriented towards the sourcecountry and (iv) account for endogeneity.

Noticeably, the above literature leaves room for extension in at least four main dimensions, notably the need to: (i) control for more terrorism indicators; (ii) explore linkages between foreign policy indicators in the terrorism-trade nexus; (iii) consider specific trade openness dimensions like resource exports and (iv) adopt robust empirical strategies that account for initial levels of the dependent variable.

First, consistent with a caution advanced by Choi (2015) on the need to explore more variables when investigating the relationship between macroeconomic indicators and terrorism, we consider a plethora of terrorism variables in order to improve room for more policy implications, namely unclear, domestic, transnational and total terrorism. The adoption of these terrorism indicators is consistent with recent literature on the relationship between terrorism and macroeconomic variables (Efobi et al., 2015; Asongu et al., 2015; Asongu \& Kodila-Tedika, 2015a). This adoption is also in line with the engaged trade-terrorism literature because some studies have focused only on a few variables, particularly (i) transnational terrorism (De Sousa et al., 2009ab) on the one hand and (ii) on the other hand transnational and domestic terrorism (Piazza, 2011).

Second, in a bid to improve space of policy directions, we are in accordance with the strand of literature which has used development assistance as a policy indicator in reducing the potentially negative impacts of terrorism on FDI (Bandyopadhyay et al., 2014; Efobi et al., 2015; Asongu et al., 2015). Hence, we steer clear of the engaged terrorism-trade literature 
by employing a foreign aid policy indicator in the terrorism- 'iron ore exports' linkage. The motivation for this deviation from the underlying literature is that foreign aid can reduce the potentially negative consequences of terrorism on trade. Moreover, motivated by the Choi (2015) recommendation (on the imperative for more policy variables), two main foreign aid variables are employed to avail room for more policy implications, notably: bilateral and multilateral aid. Based on the established evidence that terrorism reduces trade openness (Richardson, 2004; De Sousa et al., 2009ab), the intuition for involving development assistance is essentially to investigate whether foreign aid can reduce a hypothetically negative 'iron ore exports'-terrorism nexus.

Third, it is relevant to emphasise on trade-specific macroeconomic elements. Therefore, as opposed to the stream of studies discussed above, we narrow-down the perspective on iron ore exports from the broad trade openness investigated by Asongu and Kodila-Tedika (2015). We lay emphasis on natural resources because the recent growth resurgence in most developing countries has been established to be resource-driven (Amavilah, 2015). Therefore, we employ an export-specific trade category: (i) following Piazza (2011, 2012) and (ii) opposed to Nitsch and Schumacher (2004), Richardson (2004) and De Sousa et al. (2009ab).

Fourth, motivated by the caution of Mirza and Verdier (2008) on the need for more robust empirical underpinnings, we adopt an estimated technique that is robust to outliers. Moreover, the adopted Qauntile regression technique also enables us to distinguish between initial levels of iron ore exports. In essence, blanket policies may not be effective unless they are contingent on initial levels of 'iron ore exports' and tailored distinctly across high- and low- 'iron ore exports' countries.

In the light of the above, the present line of inquiry attempts to fill the gap left in the literature by assessing the role of foreign aid in reducing the hypothetically negative impact of terrorism on iron ore exports using quantile regressions. Foreign aid which is used as a policy variable is expected to dampen the potentially negative relationship that terrorism has on iron ore exports. It is logical to expect foreign aid to weaken the negative effect of terrorism on development externalities in recipient countries (including trade in terms of iron ore exports) because foreign aid is theoretically designed to increase economic output by bridging the saving-investment gap in poor countries (Easterly, 1999). Iron ore exports are part of economic output. We do not consider specific relationships between types of terrorism and 
iron ore exports. We broadly assume that terrorism (regardless of type) negatively affects an economic activity like iron ore exports ${ }^{2}$.

The empirical evidence is based on 78 developing countries with data for the period 1984-2008. The motivation for focusing on developing countries and the underlying periodicity is at least threefold. First and foremost, as documented by Gaibulloev and Sandler (2009), the negative macroeconomic consequences of terrorism are more visible in developing countries, compared to advanced economies. This is essentially because accordingly to Gaibulloev and Sandler (2009), the former set of countries lack the technological, financial and logical mechanisms needed to absorb corresponding negative externalities linked to terrorism. Second, foreign aid is channelled from developed to developing countries. Therefore, the analytical scope should be the latter set of countries. Third, a motivation of the present inquiry is also to compare corresponding findings with the stream of FDI literature that has used the same periodicity and sample, namely: Bandyopadhyay et al. (2014), Efobi et al. (2015) and Asongu et al. (2015).

The rest of the study is structured as follows. Section 2 presents the data and methodology. The empirical results, discussion and implications are covered in Section 3. Section 4 concludes with future research directions.

\section{Data and Methodology}

\subsection{Data}

We assess a panel of 78 developing countries with data for the period 1984-2008. Justifications for the choice of periodicity and sample have already been provided in the introduction. The sample that consists of three-year non-overlapping intervals is from Bandyopadhyay et al. (2014) and Efobi et al. (2015) ${ }^{3}$. The variables are originally from (i) the

\footnotetext{
${ }^{2}$ It is important to note that 'iron ore exports' can be affected by other factors like: (i) disappointing trade from steel importers and (ii) tightening of credit to steel mills (see Forbes, 2014).

${ }^{3}$ The adopted countries include: “Albania, Costa Rica, India, Namibia, Syria, Algeria, Cote d'Ivoire, Indonesia, Nicaragua, Tanzania, Angola, Dominican Republic, Iran, Niger, Thailand, Argentina, Ecuador, Jamaica, Nigeria, Togo, Bahrain, Egypt, Jordan, Pakistan, Trinidad and Tobago, Bangladesh, El Salvador, Kenya, Panama, Tunisia, Bolivia, Ethiopia, Lebanon, Papua New Guinea, Turkey, Botswana, Gabon, Libya, Paraguay, Uganda, Brazil, Gambia, Madagascar, Peru, Uruguay, Burkina Faso, Ghana, Malawi, Philippines, Venezuela, Cameroon, Guatemala, Malaysia, Saudi Arabia, Vietnam, Chile, Guinea, Mali, Senegal, Yemen, China, Guinea-Bissau, Malta, Sierra Leone, Zambia, Colombia, Guyana ,Mexico, South Africa, Zimbabwe, Congo, D. Republic, Haiti, Morocco, Sri Lanka, Congo Republic, Honduras, Mozambique and Sudan”.
} 
Global Terrorism Database, (ii) World Development indicators of the World Bank and (iii) terrorism incidents from Enders et al. (2011) and Gailbulloev et al. (2012).

The dependent variable is iron ore exports. In accordance with Asongu and KodilaTedika (2015a), independent variables of interest are terrorism indicators (domestic, unclear, transnational and total terrorisms) and foreign aid variables (multilateral and bilateral aids). Terrorism is defined in this study as the actual and threatened use of force by subnational actors with the purpose of employing intimidation to meet political objectives (Enders \& Sandler, 2006). The terrorism variables account for the number of yearly terrorism incidents registered in a country. In order to prevent mathematical concerns related to log-transforming zeros on the one hand and correct of the positive skew in the data, the study takes the natural logarithm of terrorism incidents by adding one to the base. This transformation approach is consistent with recent literature (Choi \& Salehyan, 2013; Bandyopadhyay et al., 2014). Terrorism-specific definitions are from Efobi et al. (2015, p. 6). Domestic terrorism "includes all incidences of terrorist activities that involve[s] the nationals of the venue country: implying that the perpetrators, the victims, the targets and supporters are all from the venue country" (p.6). Transnational terrorism is " terrorism including those acts of terrorism that concern[s] at least two countries. This implies that the perpetrator, supporters and incidence may be from/in one country, but the victim and target is from another". Unclear terrorism is that, "which constitutes incidences of terrorism that can neither be defined as domestic nor transnational terrorism" (p.6). Total terrorism is the sum of domestic, transnational and unclear terrorisms.

Contrary to the independent variables of interest on which this inquiry is based, the control variables help to ascertain some expected relationships between the outcome variable and other factors (institutional and macroeconomic). The control variables are: Trade openness, exchange rate, infrastructure, political globalisation, inflation, and internal conflicts. These control variables are consistent with underlying FDI-terrorism literature. From our expectations, infrastructural development, exchange rate improvement and trade openness should exert positive impacts on resource exports (Akpan, 2014; Asongu, 2015), whereas, internal/civil conflicts and inflation should have the opposite effect. These expected correlations are based on intuition and empirical literature. Accordingly, high exchange rates have been established to stimulate exports, especially in developing countries (Rodrik, 2008). High inflation is expected to decrease the volume of iron ore exports because of greater economic uncertainty. The reason for this negative effect is that high inflation reflects a 
negative economic outlook and investors have been documented to prefer strategies of investment that are void of ambiguity (Le Roux and Kelsey, 2015ab). We cannot establish the expected sign of 'political globalisation' a priori because its effect depends considerably on leverage in the international 'decision-making' processes (Asongu, 2014a). Definitions of discussed variables are provided in Table 1.

The summary statistics of the variables are provided in Table 2. The purpose of the correlation matrix provided in the appendix is to assess and prevent potential issues of multicollinearity between non-interactive variables. Contrary to linear additive models, in interactive models the issue of multicollinearity is not a concern between interactions and constituent variables (foreign aid and terrorism) (Brambor et al., 2006). However, we are not involving more than two sets of interactive variables under the same specification. In other words, whereas multicollinearity is not an issue when it comes to interactive variables (i.e: interactive terms and their constituents), we are concerned about multicollinearity between specific components of interactive terms. Hence, only one aid variable and one terrorism variable can be employed in a given interactive specification.

\section{Table 1: Definitions and Sources of Variables}

\begin{tabular}{|c|c|c|c|}
\hline Variables & Signs & Definitions & Sources \\
\hline Iron Ore Export & IOExp & Ln. Iron Ore Export (as a \% of Merchandise Exports) & \multirow{13}{*}{$\begin{array}{l}\text { Bandyopadhyay } \\
\text { et al. (2014) } \\
\text { and Efobi et al. } \\
\text { (2015) }\end{array}$} \\
\hline Trade Openness & LnTrade & Ln. of Exports plus Imports of Commodities ( $\%$ of GDP) & \\
\hline Infrastructure & LnTel & Ln. of Number of Telephone lines (per 100 people) & \\
\hline Inflation & LnInflation & Ln. of Consumer Price Index ( $\%$ of annual) & \\
\hline Exchange rate & LnXrate & Ln. of Exchange rate (local currency per USD) & \\
\hline Bilateral Aid & LnBilaid & Ln. of Bilateral aid, net disbursement (million USD) & \\
\hline Multilateral Aid & LnMulaid & Ln. of Multilateral aid, net disbursement (million USD) & \\
\hline Domestic terrorism & Domter & Number of Domestic terrorism incidents & \\
\hline $\begin{array}{l}\text { Transnational } \\
\text { terrorism }\end{array}$ & Tranater & Number of Transnational terrorism incidents & \\
\hline Unclear terrorism & Unclter & Number of terrorism incidents whose category in unclear & \\
\hline Total terrorism & Totter & Total number of terrorism incidents & \\
\hline $\begin{array}{l}\text { Political } \\
\text { globalisation }\end{array}$ & LnPolglob & Ln. of Index of political globalisation & \\
\hline Internal conflicts & Civcon & Index of internal civil conflicts & \\
\hline
\end{tabular}

GDP: Gross Domestic Product. WDI: World Development Indicators. 


\begin{tabular}{lccccc}
\hline & Mean & S.D & Minimum & Maximum & Obs \\
\cline { 2 - 5 } Iron Ore Exports (ln) & 0.698 & 2.120 & -10.495 & 4.486 & 511 \\
Trade Openness (ln) & 4.118 & 0.534 & 2.519 & 5.546 & 612 \\
Infrastructure (ln) & 1.475 & 1.017 & 0.091 & 4.031 & 616 \\
Inflation (ln) & 2.414 & 1.384 & -3.434 & 9.136 & 581 \\
Exchange rate (ln) & 2.908 & 3.870 & -22.121 & 21.529 & 618 \\
Bilateral Aid (ln) & 5.181 & 1.286 & 0.765 & 8.362 & 602 \\
Multilateral Aid (ln) & 4.163 & 1.518 & -1.249 & 7.105 & 600 \\
Domestic terrorism & 14.292 & 45.179 & 0 & 419.33 & 624 \\
Transnational terrorism & 2.316 & 6.127 & 0 & 63 & 624 \\
Unclear terrorism & 1.972 & 7.479 & 0 & 86 & 624 \\
Total terrorism & 18.581 & 55.595 & 0 & 477.66 & 624 \\
Political globalisation (ln) & 4.036 & 0.301 & 2.861 & 4.530 & 624 \\
Internal conflicts & 0.965 & 1.906 & 0 & 10 & 615 \\
\hline S.D: Stanch
\end{tabular}

S.D: Standard Deviation. Obs: Observations.

\subsection{Methodology}

Following the underlying literature on conditional determinants (Billger \& Goel, 2009) and more specifically recent terrorism-FDI studies (Asongu et al., 2015) in order to assess if initial levels of iron ore exports matter in the interactions of 'foreign aid and terrorism', we employ the quantile regression (QR) approach. It consists of investigating the determinants of iron ore exports throughout their conditional distribution (Keonker \& Hallock, 2001).

Previous studies in the FDI-terrorism (Bandyopadhyay et al., 201; Efobi et al., 2015) and trade-terrorism (Asongu \& Kodila-Tedika, 2015a) literature have reported parameter estimates at the conditional mean of the dependent variable. Whereas mean impacts are relevant, we extend the underlying literature by employing QR to distinguish between initial levels of iron ore exports. For example, while Ordinary Least Squares (OLS) assumes that the dependent variable and error terms are distributed normally, the QR approach is not based on the assumption of error terms that are normally distributed. Therefore, the techinque enables us to assess the effect of 'underlying independent variables of interest' on the dependent variable with particular emphasis on low- medium- and high-'iron ore exporting' countries. Accordingly, with QR, parameter estimates are derived at multiple points of the conditional distributions of 'iron ore' exports (Keonker \& Hallock, 2001). The QR technique is increasingly being employed in development literature, notably in: corruption (Billger \& 
Goel, 2009; Okada \& Samreth, 2012; Asongu, 2013), health (Asongu, 2014b) and financial (Asongu, 2014c) studies.

The $\theta^{\text {th }}$ quintile estimator of iron ore exports is obtained by solving for the following optimization problem, which is presented without subscripts in Eq. (1) for the purpose of simplicity and ease of presentation.

$$
\min _{\beta \in R^{k}}\left[\sum_{i \in\left\{i: y_{i} \geq x_{i^{\prime} \beta}\right\}} \theta\left|y_{i}-x_{i^{\prime}} \beta\right|+\sum_{i \in\left\{i: y_{i} \geq x_{i^{\prime}} \beta\right\}}(1-\theta)\left|y_{i}-x_{i^{\prime}} \beta\right|\right]
$$

Where $\theta \in(0,1)$. As opposed to OLS which is fundamentally based on minimizing the sum of squared residuals with $\mathrm{QR}$, the weighted sum of absolute deviations are minimised. For instance the $25^{\text {th }}$ or $75^{\text {th }}$ quintiles (with $\theta=0.25$ or 0.75 respectively) by approximately weighing the residuals. The conditional quintile of iron ore exports or $y_{i}$ given $x_{i}$ is:

$$
Q_{y}\left(\theta / x_{i}\right)=x_{i^{\prime}} \beta \theta
$$

where unique slope parameters are modelled for each $\theta^{\text {th }}$ specific quintile. This formulation is analogous to $E(y / x)=x_{i} \beta$ in the OLS slope where parameters are investigated only at the mean of the conditional distribution of iron ore exports. For the model in Eq. (2) the dependent variable $y_{i}$ is the 'iron ore' exports indicator while $x_{i}$ contains a constant term, trade openness, inflation, infrastructure, exchange rate, political globalisation and civil/internal conflicts.

Given that the estimation strategy entails interactive regressions, we briefly discuss some pitfalls documented by Brambor et al. (2006). Accordingly, all constitutive indicators are involved in the specifications. In addition, for the estimations to have economic meaning, the estimated coefficients corresponding to the interactive terms are interpreted as conditional marginal impacts. In addition, the modifying indicators or foreign aid variables should be within the ranges disclosed by the summary statistics for the overall marginal effect to make economic sense.

\section{Empirical results}

\subsection{Presentation of results}

Tables 3 and 4 disclose findings corresponding respectively to bilateral aid and multilateral aid. All the tables entail four-sets of specifications, namely: (i) domestic and transnational terrorism modelling in Panel A and (ii) unclear and total terrorism estimations in 
Panel B. More specifically, the left-hand-side (LHS) of Panel A (B) displays findings for domestic (unclear) terrorism whereas the right-hide-side (RHS) of Panel A (B) shows results for transnational (total) terrorism. For either table, we consistently notice that the QR estimates are different from the OLS estimates in terms of signs and significance. This further supports the relevance of the QR strategy.

The following findings can be established with respect to Table 3 on linkages between iron ore exports, bilateral aid and terrorism indicators. First, but for a slim exception at the $0.90^{\text {th }}$ quintile for transnational terrorism on the RHS of Panel A, the effects of terrorism are overwhelmingly insignificant. Second, bilateral aid consistently has a positive effect with (i) an inverted U-shape and (ii) threshold effects of decreasing positive magnitude from the $0.25^{\text {th }}$ to the $0.90^{\text {th }}$ quintile. Third, on the interaction effects between bilateral aid and terrorism indicators, two tendencies are noteworthy: (i) positive impacts with domestic and total terrorisms at the $0.50^{\text {th }}$ quintile respectively and (ii) negative effects with transnational terrorism at the $0.90^{\text {th }}$ quintile. The corresponding modifying thresholds are within the range of bilateral aid provided by the summary statistics, notably 0.765 to 8.362 . Accordingly: (i) the corresponding positive thresholds are $4.333(0.013 / 0.003)$ for domestic terrorism and $5.000(0.010 / 0.002)$ for total terrorism while (ii) the negative threshold is $8.352(0.142 / 0.017)$ for transnational terrorism. It follows that the amount of bilateral aid required for an overall negative effect of transnational terrorism at the $0.90^{\text {th }}$ quintile is substantially higher than the corresponding amount needed for positive thresholds effects from domestic and total terrorism at the $0.50^{\text {th }}$ quintile. Fourth, most of the control variables are significant with the expected signs. Accordingly, trade openness and infrastructural development are positively associated with natural resource exports (Apkan, 2014), while civil conflicts and inflation have negative effects. The impact of political globalisation is not significant whereas increasing exchange rate reduces iron ore exports. A possible reason for the negative effect of exchange rates could be that deteriorating exchange rates are due to falling prices in resources and a cartel of producing-countries agreeing not to increase production to reverse the falling prices. 
Table 3: Iron Ore Exports, Bilateral aid, Terrorism

Dependent Variable: Iron Ore Exports (Ln)

Panel A: Domestic Terrorism and Transnational Terrorism (independent variables)

Domestic Terrorism (Domter)

Transnational Terrorism (Tranater)

Constant

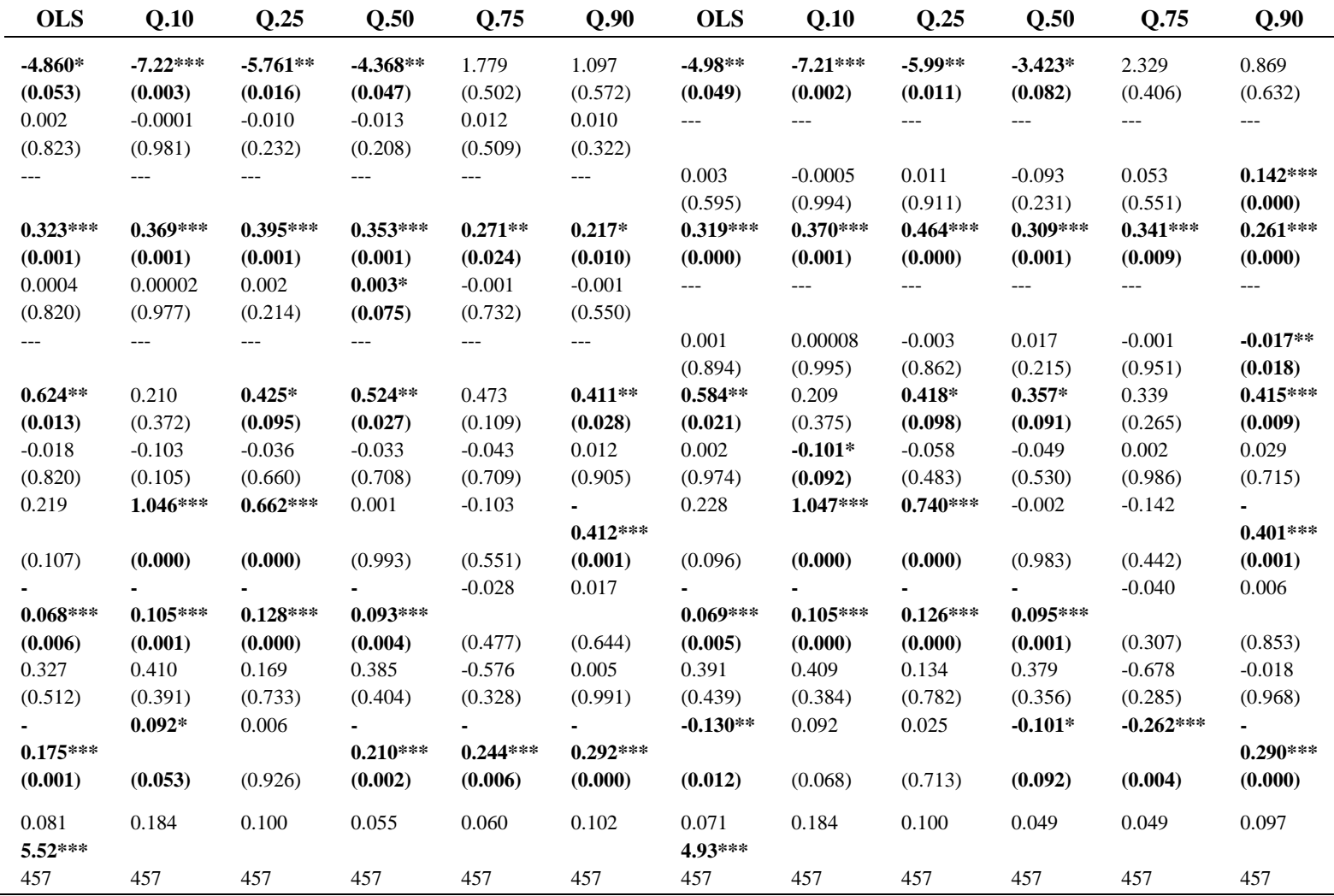

Panel B: Unclear Terrorism and Total Terrorism (independent variables)

Unclear Terrorism (Unclter)

Total Terrorism (Totter)

\begin{tabular}{|c|c|c|c|c|c|c|c|c|c|c|c|c|}
\hline Constant & $\begin{array}{l}-5.204 * * \\
(0.040)\end{array}$ & $\begin{array}{l}-7.27 * * * \\
(0.002)\end{array}$ & $\begin{array}{l}-6.57 * * * \\
(0.001)\end{array}$ & $\begin{array}{l}-4.002 * \\
(0.053)\end{array}$ & $\begin{array}{l}1.769 \\
(0.481)\end{array}$ & $\begin{array}{l}0.817 \\
(0.662)\end{array}$ & $\begin{array}{l}4.934 * * \\
(0.049)\end{array}$ & $\begin{array}{l}-7.22 * * * \\
(0.003)\end{array}$ & $\begin{array}{l}-6.39 * * * \\
(0.002)\end{array}$ & $\begin{array}{l}-4.235 * \\
(0.051)\end{array}$ & $\begin{array}{l}1.587 \\
(0.558)\end{array}$ & $\begin{array}{l}1.007 \\
(0.583)\end{array}$ \\
\hline Unclter & $\begin{array}{l}0.044 \\
(0.590)\end{array}$ & $\begin{array}{l}-0.001 \\
(0.975)\end{array}$ & $\begin{array}{l}0.0001 \\
(0.998)\end{array}$ & $\begin{array}{l}-0.072 \\
(0.296)\end{array}$ & $\begin{array}{l}0.054 \\
(0.663)\end{array}$ & $\begin{array}{l}0.042 \\
(0.422)\end{array}$ & --- & --- & --- & --- & --- & --- \\
\hline Totter & --- & --- & --- & --- & --- & --- & $\begin{array}{l}0.002 \\
(0.836)\end{array}$ & $\begin{array}{l}-0.0001 \\
(0.981)\end{array}$ & $\begin{array}{l}-0.003 \\
(0.500)\end{array}$ & $\begin{array}{l}-0.010 \\
(0.204)\end{array}$ & $\begin{array}{l}0.009 \\
(0.552)\end{array}$ & $\begin{array}{l}0.005 \\
(0.323)\end{array}$ \\
\hline LnBilaid & $\begin{array}{l}0.331 * * * \\
(0.000)\end{array}$ & $\begin{array}{l}0.369 * * * \\
(0.001)\end{array}$ & $\begin{array}{l}0.453 * * * \\
(0.000)\end{array}$ & $\begin{array}{l}0.357 * * * \\
(\mathbf{0 . 0 0 0})\end{array}$ & $\begin{array}{l}0.306 * * * \\
(0.009)\end{array}$ & $\begin{array}{l}0.174 * * \\
(0.023)\end{array}$ & $\begin{array}{l}0.323 * * * \\
(0.002)\end{array}$ & $\begin{array}{l}0.369 * * * \\
(0.001)\end{array}$ & $\begin{array}{l}0.442 * * * \\
(0.000)\end{array}$ & $\begin{array}{l}0.350 \text { **** } \\
(0.001)\end{array}$ & $\begin{array}{l}0.275^{* * *} \\
(0.030)\end{array}$ & $\begin{array}{l}0.201 * * * \\
(0.009)\end{array}$ \\
\hline Unclter * LnBilaid & $\begin{array}{l}-0.005 \\
(0.690)\end{array}$ & $\begin{array}{l}0.0002 \\
(0.967)\end{array}$ & $\begin{array}{l}-0.001 \\
(0.888)\end{array}$ & $\begin{array}{l}0.015 \\
(0.206)\end{array}$ & $\begin{array}{l}-0.004 \\
(0.830)\end{array}$ & $\begin{array}{l}-0.004 \\
(0.665)\end{array}$ & --- & --- & --- & --- & --- & --- \\
\hline Totter* LnBilaid & --- & --- & --- & --- & --- & --- & $\begin{array}{l}0.0003 \\
(0.836)\end{array}$ & $\begin{array}{l}0.00002 \\
(0.977)\end{array}$ & $\begin{array}{l}0.0006 \\
(0.552)\end{array}$ & $\begin{array}{l}0.002 * \\
(0.083)\end{array}$ & $\begin{array}{l}-0.0007 \\
(0.802)\end{array}$ & $\begin{array}{l}-0.0004 \\
(0.655)\end{array}$ \\
\hline LnTrade & $\begin{array}{l}0.598 * * \\
(0.019)\end{array}$ & $\begin{array}{l}0.212 \\
(0.383)\end{array}$ & $\begin{array}{l}0.457 * * \\
(0.041)\end{array}$ & $\begin{array}{l}0.464 * * \\
(0.040)\end{array}$ & $\begin{array}{l}0.376 \\
(0.187)\end{array}$ & $\begin{array}{l}0.386 * * \\
(0.026)\end{array}$ & $\begin{array}{l}0.626 * * \\
(0.013)\end{array}$ & $\begin{array}{l}0.210 \\
(0.372)\end{array}$ & $\begin{array}{l}0.455 * * \\
(0.034)\end{array}$ & $\begin{array}{l}0.509 * * \\
(0.030)\end{array}$ & $\begin{array}{l}0.502 \\
(0.105)\end{array}$ & $\begin{array}{l}0.401 * * \\
(0.023)\end{array}$ \\
\hline LnInflation & $\begin{array}{l}0.006 \\
(0.936)\end{array}$ & $\begin{array}{l}-0.103 * \\
(0.073)\end{array}$ & $\begin{array}{l}-0.053 \\
(0.453)\end{array}$ & $\begin{array}{l}-0.050 \\
(0.546)\end{array}$ & $\begin{array}{l}0.060 \\
(0.601)\end{array}$ & $\begin{array}{l}0.052 \\
(0.570)\end{array}$ & $\begin{array}{l}-0.014 \\
(0.857)\end{array}$ & $\begin{array}{l}-0.103 \\
(0.105)\end{array}$ & $\begin{array}{l}-0.048 \\
(0.489)\end{array}$ & $\begin{array}{l}-0.040 \\
(0.645)\end{array}$ & $\begin{array}{l}-0.050 \\
(0.667)\end{array}$ & $\begin{array}{l}0.027 \\
(0.780)\end{array}$ \\
\hline LnInfrastructure & $0.233 *$ & $1.046 * * *$ & $0.724 * * *$ & $(0.839)$ & $(0.530)$ & $\begin{array}{l}- \\
0.443 * * * \\
(0.000)\end{array}$ & $(0.108)$ & $1.046 * * *$ & $0.719 * * *$ & $(0.968)$ & -0.110 & $\begin{array}{l}- \\
0.423 * * * \\
(0.000)\end{array}$ \\
\hline LnXrate (Exchange rate) & $\begin{array}{l}- \\
0.068 * * * \\
(0.005)\end{array}$ & $\begin{array}{l}- \\
0.105 * * * \\
(0.001)\end{array}$ & $\begin{array}{l}- \\
0.121 * * * \\
(0.000)\end{array}$ & $\begin{array}{l}- \\
0.095 * * * \\
(0.002)\end{array}$ & -0.031 & -0.001 & $\begin{array}{l}- \\
0.068 * * * \\
(0.005)\end{array}$ & $\begin{array}{l}- \\
0.105 * * * \\
(0.001)\end{array}$ & $\begin{array}{l}- \\
0.122 * * * \\
(0.000)\end{array}$ & $\begin{array}{l}- \\
0.093 * * * \\
(0.004)\end{array}$ & -0.033 & 0.011 \\
\hline Ln (Political globalisation) & $\begin{array}{l}0.412 \\
(0.413)\end{array}$ & $\begin{array}{l}0.420 \\
(0.369)\end{array}$ & $\begin{array}{l}0.244 \\
(0.561)\end{array}$ & $\begin{array}{l}0.346 \\
(0.423)\end{array}$ & $\begin{array}{l}-0.587 \\
(0.299)\end{array}$ & $\begin{array}{l}0.161 \\
(0.733)\end{array}$ & $\begin{array}{l}0.341 \\
(0.494)\end{array}$ & $\begin{array}{l}0.410 \\
(0.390)\end{array}$ & $\begin{array}{l}0.214 \\
(0.606)\end{array}$ & $\begin{array}{l}0.371 \\
(0.415)\end{array}$ & $\begin{array}{l}-0.558 \\
(0.352)\end{array}$ & $\begin{array}{l}0.058 \\
(0.897)\end{array}$ \\
\hline Civil Conflicts & $-0.123 * *$ & $0.092 * *$ & $(0.502)$ & $-0.132 * *$ & $\begin{array}{l}- \\
0.244 * * * \\
(0.002)\end{array}$ & $\begin{array}{l}- \\
0.278 * * * \\
(0.000)\end{array}$ & $\begin{array}{l}- \\
0.170 * * * \\
(0.001)\end{array}$ & $0.092 *$ & $(0.566)$ & $\begin{array}{l}- \\
0.191 * * * \\
(0.006)\end{array}$ & $-0.258 * * *$ & $\begin{array}{l}- \\
0.288 * * * \\
(0.000)\end{array}$ \\
\hline
\end{tabular}




\begin{tabular}{|c|c|c|c|c|c|c|c|c|c|c|c|c|}
\hline Pseudo $\mathrm{R}^{2} / \mathrm{R}^{2}$ & 0.072 & 0.184 & 0.100 & 0.050 & 0.050 & 0.089 & 0.079 & 0.184 & 0.100 & 0.054 & 0.059 & 0.102 \\
\hline Fisher & $5.00 * * *$ & & & & & & $5.30 * * *$ & & & & & \\
\hline Observations & 457 & 457 & 457 & 457 & 457 & 457 & 457 & 457 & 457 & 457 & 457 & 457 \\
\hline
\end{tabular}

***,***: significance levels of $10 \%, 5 \%$ and $1 \%$ respectively. Bilaid: Bilateral aid. OLS: Ordinary Least Squares. $\mathrm{R}^{2}$ for OLS and Pseudo $\mathrm{R}^{2}$ for quantile regression. Lower quantiles (e.g., Q 0.1) signify nations where Iron Ore Exports is least.

The following findings can be established with respect to Table 4 on linkages between iron ore exports, multilateral aid and terrorism indicators. First, the effect of terrorism is consistently positive for: (i) domestic, transnational and total terrorism in the highest quintile and (ii) unclear terrorism in the top quintiles. Second, the effect of multilateral aid is positive only (i) in the $0.25^{\text {th }}$ quintiles for transnational, unclear and total terrorism related regressions and (ii) from the $0.25^{\text {th }}$ to the $0.75^{\text {th }}$ quintiles with decreasing magnitude. Third, the interaction effects between multilateral aid and terrorism indicators are only significant in the highest quintile for unclear terrorism with a negative sign. The corresponding modifying threshold is within the range (-1.249 to 7.105$)$ of multilateral aid provided by the summary statistics, notably $5.909(0.065 / 0.011)$. Fourth, most of the significant control variables have the expected signs. Accordingly, relative to Table 3, the slim exceptions are that (i) inflation is now insignificant and (ii) the effect of political globalization is positive, which is consistent with Rudra and Jensen (2011).

Table 4: Iron Ore Exports, Multilateral Aid, Terrorism

\begin{tabular}{|c|c|c|c|c|c|c|c|c|c|c|c|c|}
\hline & \multicolumn{12}{|c|}{ Dependent Variable: Iron Ore Exports } \\
\hline & \multicolumn{12}{|c|}{ Panel A: Domestic Terrorism and Transnational Terrorism (independent variables) } \\
\hline & \multicolumn{6}{|c|}{ Domestic Terrorism (Domter) } & \multicolumn{6}{|c|}{ Transnational Terrorism (Tranater) } \\
\hline & OLS & Q.10 & Q.25 & Q.50 & Q.75 & Q.90 & OLS & Q.10 & Q.25 & Q.50 & Q.75 & Q.90 \\
\hline Constant & $\begin{array}{l}-4.342 * \\
(0.089)\end{array}$ & $\begin{array}{l}-8.371 * * \\
(0.026)\end{array}$ & $\begin{array}{l}-5.54 * * * \\
(0.003)\end{array}$ & $\begin{array}{l}-3.023 \\
(0.118)\end{array}$ & $\begin{array}{l}2.432 \\
(0.186)\end{array}$ & $\begin{array}{l}1.862 \\
(0.315)\end{array}$ & $\begin{array}{l}-4.467 * \\
(0.082)\end{array}$ & $\begin{array}{l}-8.136 * * \\
(0.027)\end{array}$ & $\begin{array}{l}-5.77 * * * \\
(0.004)\end{array}$ & $\begin{array}{l}-3.221 \\
(0.126)\end{array}$ & $\begin{array}{l}3.336 \\
(0.249)\end{array}$ & $\begin{array}{l}2.214 \\
(0.316)\end{array}$ \\
\hline Domter & $\begin{array}{l}0.002 \\
(0.554)\end{array}$ & $\begin{array}{c}0.003 \\
(0.674)\end{array}$ & $\begin{array}{l}0.002 \\
(0.512)\end{array}$ & $\begin{array}{l}-0.001 \\
(0.643)\end{array}$ & $\begin{array}{l}0.004 \\
(0.273)\end{array}$ & $\begin{array}{l}0.003 * \\
(0.050)\end{array}$ & --- & --- & --- & --- & --- & --- \\
\hline Tranater & --- & --- & --- & --- & --- & --- & $\begin{array}{l}0.006 \\
(0.807)\end{array}$ & $\begin{array}{l}0.006 \\
(0.903)\end{array}$ & $\begin{array}{l}0.018 \\
(0.529)\end{array}$ & $\begin{array}{l}-0.022 \\
(0.386)\end{array}$ & $\begin{array}{l}0.040 \\
(0.243)\end{array}$ & $\begin{array}{l}0.059 * * * \\
(0.000)\end{array}$ \\
\hline LnMulaid & $\begin{array}{l}0.065 \\
(0.415)\end{array}$ & $\begin{array}{l}0.234 \\
(0.102)\end{array}$ & $\begin{array}{l}0.242 * * * \\
(0.004)\end{array}$ & $\begin{array}{l}0.143 * \\
(0.090)\end{array}$ & $\begin{array}{l}0.140 * \\
(0.076)\end{array}$ & $\begin{array}{l}-0.068 \\
(0.293)\end{array}$ & $\begin{array}{l}0.066 \\
(0.428)\end{array}$ & $\begin{array}{l}0.221 \\
(0.111)\end{array}$ & $\begin{array}{l}0.252 * * * \\
(0.007)\end{array}$ & $\begin{array}{l}0.095 \\
(0.310)\end{array}$ & $\begin{array}{l}0.128 \\
(0.287)\end{array}$ & $\begin{array}{l}-0.013 \\
(0.868)\end{array}$ \\
\hline Domter* LnMulaid & $\begin{array}{l}0.0005 \\
(0.609)\end{array}$ & $\begin{array}{l}-0.0005 \\
(0.742)\end{array}$ & $\begin{array}{l}-0.0001 \\
(0.885)\end{array}$ & $\begin{array}{l}0.001 \\
(0.145)\end{array}$ & $\begin{array}{l}0.0005 \\
(0.523)\end{array}$ & $\begin{array}{l}-0.000 \\
(0.989)\end{array}$ & --- & --- & --- & --- & --- & --- \\
\hline Tranater* LnMulaid & --- & --- & --- & --- & --- & --- & $\begin{array}{l}0.002 \\
(0.804)\end{array}$ & $\begin{array}{l}0.001 \\
(0.906)\end{array}$ & $\begin{array}{l}-0.004 \\
(0.647)\end{array}$ & $\begin{array}{l}0.006 \\
(0.439)\end{array}$ & $\begin{array}{l}-0.00009 \\
(0.990)\end{array}$ & $\begin{array}{l}-0.005 \\
(0.221)\end{array}$ \\
\hline LnTrade & $\begin{array}{l}0.578^{* *} \\
(0.020)\end{array}$ & $\begin{array}{l}0.462 \\
(0.213)\end{array}$ & $\begin{array}{l}0.520 * * * \\
(0.008)\end{array}$ & $\begin{array}{l}0.249 \\
(0.234)\end{array}$ & $\begin{array}{l}0.475^{* *} \\
(0.022)\end{array}$ & $\begin{array}{l}0.337 * * \\
(0.041)\end{array}$ & $\begin{array}{l}0.549 * * \\
(0.028)\end{array}$ & $\begin{array}{l}0.481 \\
(0.181)\end{array}$ & $\begin{array}{l}0.532 * * \\
(0.012)\end{array}$ & $\begin{array}{l}0.192 \\
(0.398)\end{array}$ & $\begin{array}{l}0.254 \\
(0.424)\end{array}$ & $\begin{array}{l}0.323 * \\
(0.082)\end{array}$ \\
\hline LnInflation & $\begin{array}{l}-0.027 \\
(0.747)\end{array}$ & $\begin{array}{l}-0.065 \\
(0.502)\end{array}$ & $\begin{array}{l}-0.086 \\
(0.191)\end{array}$ & $\begin{array}{l}-0.093 \\
(0.249)\end{array}$ & $\begin{array}{l}-0.015 \\
(0.853)\end{array}$ & $\begin{array}{l}-0.047 \\
(0.591)\end{array}$ & $\begin{array}{l}-0.014 \\
(0.867)\end{array}$ & $\begin{array}{l}-0.070 \\
(0.461)\end{array}$ & $\begin{array}{l}-0.073 \\
(0.305)\end{array}$ & $\begin{array}{l}-0.078 \\
(0.368)\end{array}$ & $\begin{array}{l}-0.014 \\
(0.908)\end{array}$ & $\begin{array}{l}0.010 \\
(0.911)\end{array}$ \\
\hline LnInfrastructure & 0.102 & $0.941 * * *$ & $0.592 * * *$ & -0.039 & -0.201 & $\begin{array}{l}- \\
0.501 * * * *\end{array}$ & 0.107 & $0.931 * * *$ & $0.604 * * *$ & -0.093 & -0.193 & $-0.446 * * *$ \\
\hline & $(0.466)$ & $(0.000)$ & $(0.000)$ & $(0.765)$ & $(0.136)$ & (0.001) & $(0.445)$ & $(0.000)$ & $(0.000)$ & $(0.512)$ & (0.349) & (0.002) \\
\hline LnXrate (Exchange rate) & $\begin{array}{l}-\mathbf{0 . 0 6 1} * * \\
(0.020)\end{array}$ & $\begin{array}{l}- \\
0.089 * * * \\
(0.003)\end{array}$ & $\begin{array}{l}- \\
0.119 * * * \\
(0.000)\end{array}$ & $\begin{array}{l}- \\
0.103 * * * \\
(0.000)\end{array}$ & $\begin{array}{l}-0.030 \\
(0.258)\end{array}$ & $(0.661)$ & $\begin{array}{l}- \\
0.063 * * * \\
(0.018)\end{array}$ & $\begin{array}{l}- \\
0.093 * * * \\
(0.001)\end{array}$ & $\begin{array}{l}- \\
0.117 * * * \\
(0.000)\end{array}$ & $\begin{array}{l}-0.087 * * * \\
(0.005)\end{array}$ & $\begin{array}{l}-0.026 \\
(0.542)\end{array}$ & $\begin{array}{l}0.005 \\
(0.860)\end{array}$ \\
\hline Ln (Political globalisation) & $\begin{array}{l}0.633 \\
(0.215)\end{array}$ & $\begin{array}{l}0.675 \\
(0.398)\end{array}$ & $\begin{array}{l}0.317 \\
(0.427)\end{array}$ & $\begin{array}{l}\text { 0.701* } \\
(0.089)\end{array}$ & $\begin{array}{l}-0.533 \\
(0.178)\end{array}$ & $\begin{array}{l}0.332 \\
(0.456)\end{array}$ & $\begin{array}{l}0.687 \\
(0.183)\end{array}$ & $\begin{array}{l}0.621 \\
(0.428)\end{array}$ & $\begin{array}{l}0.336 \\
(0.436)\end{array}$ & $\begin{array}{l}0.845 * \\
(0.058)\end{array}$ & $\begin{array}{l}-0.515 \\
(0.406)\end{array}$ & $\begin{array}{l}0.152 \\
(0.774)\end{array}$ \\
\hline
\end{tabular}




\begin{tabular}{|c|c|c|c|c|c|c|c|c|c|c|c|c|}
\hline \multirow[t]{2}{*}{ Civil Conflicts } & $-0.132 * *$ & 0.093 & 0.034 & $-0.139 * *$ & - & - & $-0.094 *$ & 0.082 & 0.042 & -0.055 & $-0.233 * *$ & $-0.272 * * *$ \\
\hline & $(0.021)$ & $(0.245)$ & $(0.549)$ & $(0.022)$ & $\begin{array}{l}0.239 * * * \\
(0.000)\end{array}$ & $\begin{array}{l}0.280 * * * \\
(0.000)\end{array}$ & $(0.080)$ & $(0.280)$ & $(0.490)$ & $(0.389)$ & $(0.013)$ & $(0.000)$ \\
\hline Pseudo $\mathrm{R}^{2} / \mathrm{R}^{2}$ & 0.052 & 0.148 & 0.078 & 0.032 & 0.047 & 0.096 & 0.045 & 0.149 & 0.078 & 0.027 & 0.036 & 0.089 \\
\hline Fisher & $2.95 * * *$ & & & & & & $2.80 * * *$ & & & & & \\
\hline Observations & 453 & 453 & 453 & 453 & 453 & 453 & 453 & 453 & 453 & 453 & 453 & 453 \\
\hline
\end{tabular}

Panel B: Unclear Terrorism and Total Terrorism (independent variables)

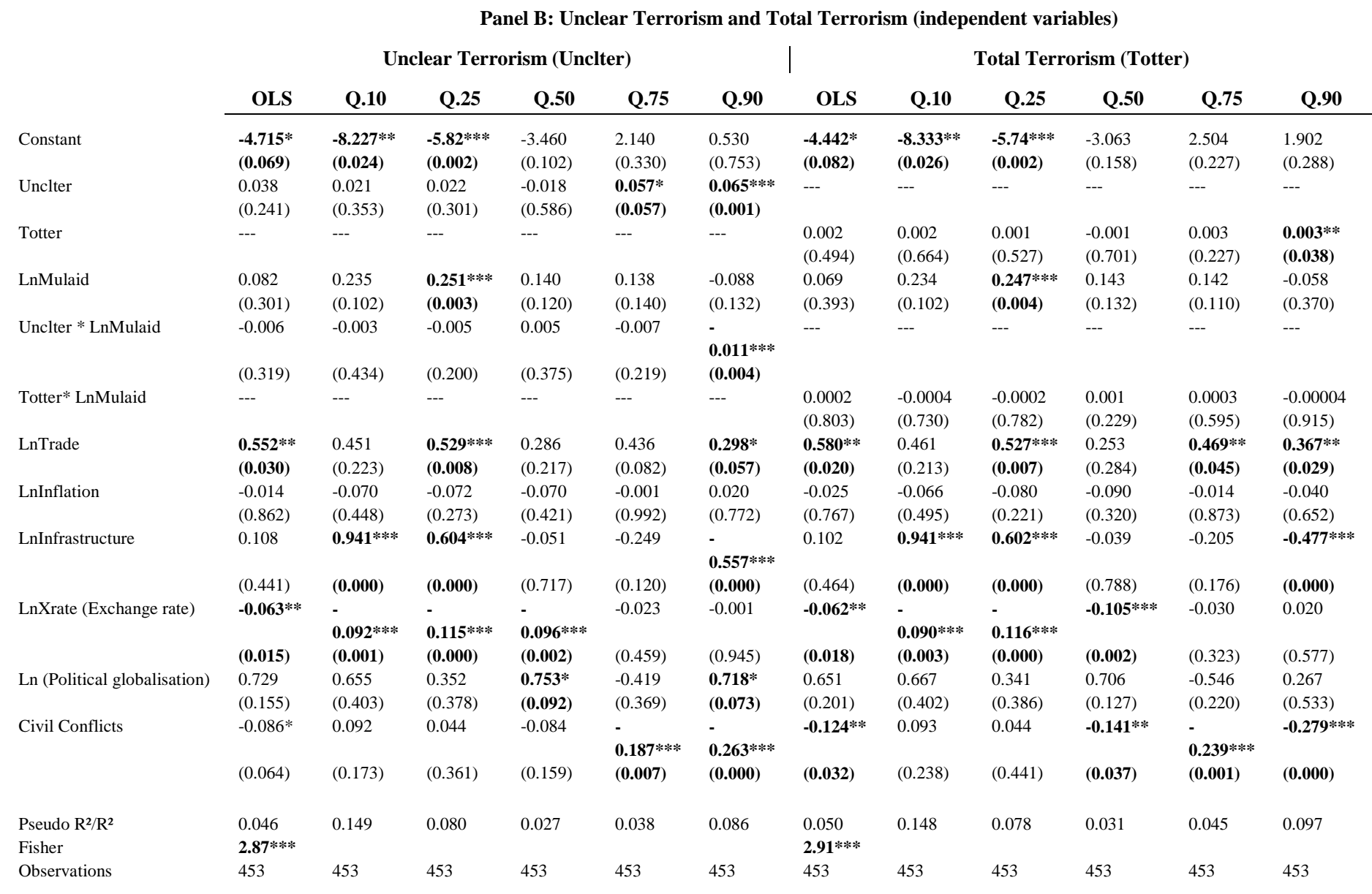

***,***: significance levels of $10 \%, 5 \%$ and $1 \%$ respectively. Mulaid: Multilateral aid. OLS: Ordinary Least Squares. $\mathrm{R}^{2}$ for OLS and Pseudo $\mathrm{R}^{2}$ for quantile regression. Lower quantiles (e.g., Q 0.1) signify nations where Iron Ore Exports are least.

\subsection{Further discussion and policy implications}

For brevity, lack of space and in the interests of clarity, we further engage the results along three main themes, notably, the: (i) expected positive effect of terrorism in some distributions; (ii) overwhelming positive impact of bilateral aid as opposed to multilateral aid and (iii) positive interactions between bilateral aid and some terrorism indicators.

First, the results suggest that it is primarily in the countries with the highest levels of iron ore exports that terrorism affects exports, especially in 'multilateral aid'-oriented regressions. This implies terrorist activities may exert some positive effects in countries with the highest levels of iron ore exports. The causality flowing from terrorism to iron ore exports is broadly consistent with the results of De Sousa et al. (2009ab), Richardson (2004) and 
Nitsch and Schumacher (2004) on the terrorism-trade nexus discussed in the literature. A logical explanation for this unexpected positive effect is that countries with the highest levels of iron ore exports may be inclined to increase production in an attempt to boost the much needed government revenue essential for combating rising terrorism. This interpretation may also be contingent on the fact that iron ore exports from countries with the highest level of iron ore exports represents a significant part of export and government revenue. It should be noted that we have consistently found all terrorism variables to exert a positive influence on the dependent variable in countries with the highest levels of iron ore exports.

An extension of the interpretation is traceable to the fact that remote terrorist incidences may increase investment appetite in iron ore exploration. This is in line with the conclusions of De Sousa et al. (2009b) that with remoteness in terror, trade increases. Accordingly, this intuition is premised on the logic that the will of some natural resource investors to invest in the iron ore industry could be more than proportionate to an underlying remote terrorism if expected short- medium- and long-term returns are projected to outweigh underlying terrorist risks. Some contemporary parallel examples in other resource industries include (i) growing Chinese investment in Nigeria's Delta region in spite of growing threats from the Movement for the Emancipation of the Niger Delta (MEND) (Obi, 2008) and (ii) the Chinese unrelenting presence in South Sudan, despite increasing violence because the country accounts for 5\% of its crude oil imports (Aguirre, 2014). This interpretation is in accordance with Elu and Price (2010) and Asongu and Aminkeng (2013) on Chinese oil diplomacy and long-run economic strategy of continuing to engage with countries which are characterised by civil conflicts, violence and political strife. As a policy implication, terrorists' activities do not exclusively exert negative effects on resource exports.

Second, we have found that relative to multilateral aid, the effects of bilateral aid are more significant. Accordingly, the effect of bilateral aid is consistently positive with an inverted U-shape and threshold effects of decreasing positive magnitude, whereas multilateral aid is overwhelmingly positive only in the $0.25^{\text {th }}$ quintiles. The relative effectiveness of bilateral aid which is consistent with Asongu et al. (2015) and Asongu and Kodila-Tedika (2015) can be traceable to the political economy of development assistance. Accordingly, because the strings related to bilateral aid require less conflicting development interest, as opposed to multilateral aid which may be (i) clouded by conflicts of interest during 'consensus building' among donors and hence (ii) tailored towards varying donor objectives. While a recent survey of the literature has failed to establish differences in development 
outcomes of multilateral aid vis-à-vis bilateral aid (Biscaye et al., 2015), the intuition of this interpretation is consistent with available evidence that former colonial powers who have various strategic interests in former colonies may be more effective at allocating foreign aid towards the fight against terrorism and the export of natural resources ${ }^{4}$. Recent evidence on France's intervention in Mali, the Central African Republic and exploitation of uranium in Niger confirm this position (Melly \& Darracq, 2013). As a policy implication, the results suggest that bilateral aid has an impact on iron ore export, while the evidence for such a relationship between multilateral aid and iron ore exports is limited.

Third, on interactions between bilateral aid and terrorism indicators, two tendencies are noteworthy. They are: (i) positive impacts with domestic and total terrorisms at the $0.50^{\text {th }}$ quintile respectively and (ii) a negative effect with transnational terrorism at the $0.90^{\text {th }}$ quintile. Moreover, the interaction effect between multilateral aid and terrorism variables is only significant in the highest quintile for unclear terrorism with a negative sign. The modifying foreign aid thresholds are within range. This provides limited support for the main hypothesis motivating this line of inquiry, notably that foreign can be used to mitigate a potentially negative effect of terrorism on resource exports. Such development assistance may provide the much needed technical, logistical and financial means essential for absorbing and/or reversing potential negative resource export externalities associated with terrorism. The interpretation is consistent with the position of Asongu and Kodila-Tedika (2015a) on narratives from Gaibulloev and Sandler (2009) that countries with more financial leverage are better equipped to absorb the negative macroeconomic effects of terrorism. A position also consistent with Öcal and Yildirim (2010) and Meierrieks and Gries (2013). As a policy implication, given that the modifying thresholds are within range, bilateral aid may be relevant at mitigating the negative effects of domestic and total terrorism on iron ore exports. It is important to note that foreign aid would contribute to total financial resources, but it is not evident that the aid will be sufficient to make these countries belong to the group of better equipped countries.

\footnotetext{
${ }^{4}$ The position on conflicting donor interest is consistent with the conclusions of Asongu (2014d) "Aid is the outcome of bargaining in a kind of political market made up of donor aid bureaucracies, multilateral aid agencies and recipient government officials. Indeed donors pursue multiple goals and these vary over time. For instance, economic gains seem important in Japanese aid, global welfare improvement in Nordic aid and political goals in French aid. Hence, few would object to the inference that our findings may also be explained by a motivation of the French to maintain their colonial legacies and influence in Africa" (p. 472).
} 
In accordance with the motivation of this line of inquiry which has been partially based on comparing the findings with studies in the terrorism literature that have employed the same sample and periodicity, we devote some space to discussing how our findings have improved insights into linkages between terrorism and macroeconomic variables. First and foremost, while Bandyopadhyay et al. (2014) using Generalised Method of Moments (GMM) have focused on how development assistance could be relevant in mitigating the negative impact of terrorism on FDI. Their results have been extended by Efobi et al. (2015) and Asongu et al. (2015) who have respectively conditioned the baseline analysis on (i) domestic corruption-control levels using a more robust GMM strategy and (ii) initial levels of foreign direct investment using quintile regressions. Moreover, findings from the last-two studies have not been consistent with Bandyopadhyay et al. (2014) on (i) an exclusive negative terrorism-FDI and (ii) a positive effect on FDI from the interaction between aid and terrorism. This study has improved existing knowledge in the evolving stream of literature by: (i) employing iron ore exports as the dependent variable; (ii) partially confirming the findings of Bandyopadhyay et al. (2014) in terms the effects of terrorism, foreign aid and their related interactions on macroeconomic variables and (iii) validating the results of Efobi et al. (2015) and Asongu et al. (2015) only within the spectra of negative interactive impacts and positive effect of terrorism on external flows.

\section{Concluding implications and further research}

Building on evidence that terrorism reduces trade openness, we have employed quantile regressions to assess conditional linkages between foreign aid, iron ore exports and terrorism in a panel of 78 developing countries for the period 1984-2008. Bilateral and multilateral aid indicators have been used while terrorism has entailed domestic, transnational, unclear and total terrorism indicators. The following findings have been established. First, the effect of terrorism is positively significant for the most part in the highest quintiles. Second, the effect of bilateral aid is consistently positive with an inverted U-shape and threshold effects of decreasing positive magnitude, whereas multilateral aid is overwhelmingly positive only in the $0.25^{\text {th }}$ quintiles. Third, interactions between bilateral aid and terrorism variables reveal positive impacts with domestic and total terrorisms at the median quintiles and negative effects with transnational terrorism at the highest quintile, whereas the interaction between multilateral aid and terrorism indicators is only significant with a negative sign in the highest quintile for unclear terrorism. The modifying foreign aid 
thresholds that are within range further confirm the relevance of bilateral aid in mitigating the negative effects of domestic and total terrorism on iron ore exports. Justifications for unexpected signs have been are discussed.

Three policy implications are apparent. First, terrorists' activities do not exclusively exert negative effects on resource exports. Second, bilateral aid has an impact on iron ore exports, while the evidence for such a relationship between multilateral aid and iron ore exports is limited. Third, given that the modifying thresholds are within range, bilateral aid is relevant at mitigating the negative effects of domestic and total terrorism on iron ore exports. In the light of the discussed findings, there is evidently room for future research in (i) understanding mechanisms by which terrorism positively and negatively affects iron ore exports and (ii) distinguishing aid by sectors to improve insights into which aid-specific categories are most relevant in the established linkages. 


\section{Appendix}

\section{Correlation Matrix}

\begin{tabular}{|c|c|c|c|c|c|c|c|c|c|c|c|c|c|}
\hline LnIOExp & LnTrade & LnTel & LnInflation & LnXrate & LnBilad & LnMulaid & Domter & Tranater & Unclter & Totter & LnPolglob & Civcon & \\
\hline \multirow[t]{13}{*}{1.000} & 0.103 & 0.080 & -0.001 & -0.055 & 0.126 & 0.025 & 0.049 & 0.0007 & -0.001 & 0.040 & 0.109 & -0.079 & LnIOExp \\
\hline & 1.000 & 0.296 & -0.230 & 0.043 & -0.267 & -0.289 & -0.236 & -0.206 & -0.240 & -0.246 & -0.122 & -0.299 & LnTrade \\
\hline & & 1.000 & -0.121 & -0.191 & -0.376 & -0.514 & 0.023 & 0.072 & -0.003 & 0.026 & 0.268 & -0.183 & LnTel \\
\hline & & & 1.000 & -0.284 & -0.047 & -0.023 & 0.171 & 0.164 & 0.091 & 0.169 & -0.150 & 0.185 & LnInflation \\
\hline & & & & 1.000 & 0.114 & 0.183 & -0.081 & -0.001 & -0.050 & -0.073 & 0.089 & -0.120 & LnXrate \\
\hline & & & & & 1.000 & 0.721 & 0.116 & 0.088 & 0.093 & 0.117 & 0.233 & 0.259 & LnBilaid \\
\hline & & & & & & 1.000 & 0.014 & -0.039 & 0.069 & 0.016 & 0.167 & 0.194 & LnMulaid \\
\hline & & & & & & & 1.000 & 0.743 & 0.733 & 0.993 & 0.127 & 0.428 & Domter \\
\hline & & & & & & & & 1.000 & 0.528 & 0.785 & 0.120 & 0.418 & Tranater \\
\hline & & & & & & & & & 1.000 & 0.789 & 0.072 & 0.347 & Unclter \\
\hline & & & & & & & & & & 1.000 & 0.126 & 0.441 & Totter \\
\hline & & & & & & & & & & & 1.000 & -0.024 & LnPolglob \\
\hline & & & & & & & & & & & & 1.000 & Civcon \\
\hline
\end{tabular}

LnIOIxp: Iron Ore Export. LnTrade: Trade Openness. LnTel: Number of Telephone lines. LnXrate: Exchange rate. LnBilaid: Bilateral aid. LnMulaid: Multilater aid. Domter: Number of Domestic terrorism incidents. Tranater: Number of Transnational terrorism incidents. Unclter: Number of terrorism incidents whose category in unclear. Totter: Total number of terrorism incidents. LnPolglob: Index of political globalisation.

Civcon: Index of internal civil conflicts. 


\section{References}

Abadie, A., \& Gardeazabal, J., (2008. "Terrorism and the world economy", European Economic Review, 52(1), pp.1-27.

Aguirre, I., (2014). "Violence in South Sudan Threatens Chinese Oil Investment", Global Risk Insights http://oilprice.com/Energy/Crude-Oil/Violence-In-South-Sudan-Threatens-Chinese-OilInvestment.html (Accessed: 11/07/2015).

Akinwale, A. K., (2010). "Integrating the traditional and the modern conflict management strategies in Nigeria”, Department of Sociology, Faculty of Social Sciences, University of Ibadan, Nigeria.

Akpan, U., (2014). "Impact of Regional Road Infrastructure Improvement on Intra-Regional Trade in ECOWAS", African Development Review, 16(S1), pp. 64-76.

Amavilah, V. H., (2015). "Social Obstacles to Technology, Technological Change, and the Economic Growth of African Countries: Some Anecdotal Evidence from Economic History", MPRA Paper No. 63273.

Anderson, M., (2015), "Global cost of conflict reaches \$14.3 tn, says report", The guardian, http://www.theguardian.com/global-development/2015/jun/16/global-cost-conflict-reaches14tn-says-report (Accessed: 27/06/2015).

Asongu, S. A., (2013). "Fighting corruption in Africa: do existing corruption-control levels matter?", International Journal of Development Issues, 12(1), pp. 36-52.

Asongu, S. A., (2014a). "Globalization (fighting), corruption and development: How are these phenomena linearly and nonlinearly related in wealth effects?", Journal of Economic Studies, 3(3), pp. 346-369.

Asongu, S. A., (2014b). "The impact of health worker migration on development dynamics: evidence of wealth effects from Africa", The European Journal of Health Economics, 15(2), pp. 187-201.

Asongu, S. A., (2014c). "Financial development dynamics thresholds of financial globalisation: evidence from Africa”, Journal of Economic Studies, 41(2), pp. 166-195.

Asongu, S. A., (2014d). "The Questionable Economics of Development Assistance in Africa: Hot-Fresh Evidence, 1996-2010", The Review of Black Political Economy, 41(4), pp. 455480.

Asongu, S. A., (2015). "Drivers of Growth in Fast Emerging Economies: A Dynamic Instrumental Quantile Approach”, African Governance and Development Institute Working Paper No. 15/009, Yaoundé.

Asongu, S. A., \& Aminkeng, G. A. A., (2013). "The economic consequences of China-Africa relations: debunking myths in the debate", Journal of Chinese Economic and Business Studies, 11(4), pp. 261-277. 
Asongu, S. A., Efobi, U., \& Beecroft, I., (2015). "FDI, Aid, Terrorism: Conditional Threshold Evidence from Developing Countries", African Governance and Development Institute Working Paper No. 15/019, Yaoundé.

Asongu, S. A., \& Kodila-Tedika, O., (2015a). "Trade, Aid and Terror", African Governance and Development Institute Working Paper No. 15/028, Yaoundé.

Asongu, S. A., \& Kodila-Tedika, O., (2015b). "Is Poverty in the African DNA (Gene)?", African Governance and Development Institute Working Paper No. 15/011, Yaoundé.

Asongu, S. A., \& Kodila-Tedika, O., (2016). "Fighting African Conflicts and Crime: Which Governance Tools Matter?", International Journal of Social Economics: 43(5), pp. 466-485.

Asongu, S. A., \& Nwachukwu, J. C., (2015a). "Revolution empirics: predicting the Arab Spring", Empirical Economics:

DOI: $10.1007 \% 2$ Fs00181-015-1013-0

Asongu, S. A., \& Nwachukwu, J. C., (2015b). "Fighting terrorism: empirics on policy harmonization", African Governance and Development Institute Working Paper No. 15/024, Yaoundé.

Asongu, S. A., \& Nwachukwu, J. C., (2016). "The Role of Lifelong Learning in Political Stability and Non-violence: Evidence from Africa", Journal of Economic Studies, 43(1), pp. 141-164.

Bandyopadhyay, S., Sandler, T., \& Younas, J., (2014). "Foreign direct investment, aid, and terrorism", Oxford Economic Papers, 66(1), pp. 25-50.

Beets, S. D., (2005). "Understanding the Demand-Side Issues of International Corruption." Journal of Business Ethics, 57 (1), pp. 65-81.

Bell, S. R., Clay, K. C., Murdie, A., \& Piazza, J., (2014). "Opening Yourself Up: The Role of External and Internal Transparency in Terrorism Attacks", Political Research Quarterly: doi:10.1177/1065912914527798.

Billger, S. M., \& Goel, R. K., (2009), "Do existing corruption levels matter in controlling corruption? Cross-country quantile regression estimates", Journal of Development Economics, 90, pp. 299-305.

Biscaye, P., Harris, K. P., Reynolds, T., \& Anderson, C. L., (2015). "Relative Effectiveness of Bilateral and Multilateral Aid on Development and Social Outcomes", Evans School of Policy Analysis and Research (EPAR) Brief No. 294, Seattle, Washington.

Black, D., (1990). The elementary forms of conflict management. New York, Plenum Press.

Borg, M. J., (1992). "Conflict management in the modern world-system". Sociological Forum, 7(2), pp. 261-282. 
Brambor, T., Clark, W. M., \& Golder, M., (2006), “Understanding Interaction Models: Improving Empirical Analyses”, Political Analysis, 14 (1), pp. 63-82.

Brockhoff, S., Kieger, T., \& Meierrieks, D., (2014). "Great Expectations and Hard Times The (Nontrivial) Impact of Education on Domestic Terrorism", Journal of Conflict Resolution: doi: 10.1177/0022002713520589.

Caulderwood, K., (2015) "Sub-Saharan Africa Falls Behind In Fight Against Extreme Poverty: World Bank Report”, International Business Times (April 14th 2015). http://www.ibtimes.com/sub-saharan-africa-falls-behind-fight-against-extreme-povertyworld-bank-report-1881460 (Accessed: 19/04/2015).

Choi, S-W., (2015). "Economic growth and terrorism: domestic, international, and suicide", Oxford Economic Papers, 67(1), pp. 157-181.

Choi, S-W., (2010). "Fighting Terrorism through the Rule of Law?", The Journal of Conflict Resolution, 54(6), pp. 940-966.

Choi, S-W., \& Salehyan , I., (2013). "No Good Deed Goes Unpunished: Refugees, Humanitarian Aid, and Terrorism", Conflict Management and Peace Sciences, 30(1), pp. 5375.

Costa, A., Hermandez, M., \& Sebastian-Gallés, N., (2008). "Bilingualism aids conflict resolution: Evidence from the ANT task", Cognition, 106 (1), pp. 59-86.

De Sousa, J., Mirza, D., \& Verdier, T., (2009a), "Trade and the Spillovers of Transnational Terrorism”, Swiss Society of Economics and Statistics, 145 (4), pp. 453-461.

De Sousa, J., Mirza, D., \& Verdier, T., (2009b), “Terrorism Networks and Trade: Does the Neighbor Hurt?”, CEPR Discussion Paper No. DP7946.

Easterly, W., (1999. "The Ghost of Financing Gap: Testing the Growth Model Used in the International Financial Institutions", Journal of Development Economics, 60, pp. 423-438.

Enders, W., \& Sandler T., (2006). The Political Economy of Terrorism. New York:

Cambridge University Press.

Enders W, Sandler T \& Gaibulloev K., (2011). "Domestic versus transnational terrorism: Data, decomposition, and dynamics”. Journal of Peace Research, 48(3), pp. 319-337.

Efobi, U., Asongu, S., \& Beecroft, I., (2015). "Foreign Direct Investment, Aid and Terrorism: Empirical Insight Conditioned on Corruption Control”, African Governance and Development Institute Working Paper No. 15/007, Yaoundé.

Elu, J. U., \& Price, G. N., (2010). "Does China Transfer Productivity Enhancing Technology to Sub-Saharan Africa? Evidence from Manufacturing Firms", African Development Review, 22(1), pp. 587-598. 
Feridun, M., \& Shahbaz, M., (2010). "Fighting Terrorism: Are Military Measures Effective? Empirical Evidence from Turkey”, Defence \& Peace Economics, 21(2), pp. 193-205.

Forbes (2014). "The Latest Iron Ore Price Slump: Causes And Effects", Forbes/Investing, http://www.forbes.com/sites/greatspeculations/2014/03/14/the-latest-iron-ore-price-slumpcauses-and-effects/\#fad3ef06949d (Accessed: 19/04/2016).

Gaibulloev, K., \& Sandler, T., (2009). "The impact of terrorism and conflicts on growth in Asia”, Economics and Politics, 21(3), pp. 359-383.

Gailbulloev, K., Sandler, T., \& Santifort, C., (2012). "Assessing the Evolving Threat of Terrorism", Global Policy, 3(2), pp. 135-144.

Gardner, K. L., (2007). "Fighting Terrorism the FATF Way". Global Governance: A Review of Multilateralism and International Organisation, 13(3), pp. 325-345.

Gries, T., Krieger, T., \& Meierrieks, D., (2011). "Causal Linkages Between Domestic Terrorism and Economic Growth", Defence and Peace Economics, 22(5), pp. 493-508.

Heyneman, S. P., (2002). "Defining the Influence of Education on Social Cohesion", International Journal of Educational Policy, Research and Practice, 3(4), pp. 73-97.

Heyneman, S. P., (2008a). "Education, social cohesion and ideology. In Right to Education: Policies and Perspectives, edited by Emin Karip, 89-104. Ankara: Turkish Education Association.

Heyneman, S. P., (2008b). "Buying your way into Heaven: The corruption of education systems in global perspective.", Perspectives on Global Issues, 2 (1), pp. 1-8.

Hoffman, A. M., Shelton, C., \& Cleven, E., (2013). "Press Freedom, Publicity, and the CrossNational Incidence of Transnational Terrorism", Political Research Quarterly, 66(4), pp. 896-909.

Humphreys, M., (2005). "Natural Resources, Conflict, and Conflict Resolution. Uncovering the Mechanisms", Journal of Conflict Resolution, 49 (4), pp. 508-537.

International Country Risk Guide. (2010) The political risk services group, available at http://www.prsgroup.com/icrg.aspx (Accessed 10 October 2010).

Koenker, R., \& Hallock, F.K., (2001), “Quantile regression”, Journal of Economic Perspectives, 15, pp.143-156.

Koh, W. T. H., (2007). "Terrorism and its impact on economic growth and technological innovation”, Technological Forecasting and Social Change, 74(2), pp. 129-138.

Le Roux, S., \& Kelsey, D., (2015a). "Dragon Slaying with Ambiguity: Theory and Experiments", Sara le Roux, Department of Economics, Oxford Brookes University.

Le Roux, S., \& Kelsey, D., (2015b). "Strategic Substitutes, Complements and Ambiguity: An 
Experimental Study", Department of Economics, Oxford Brookes University.

Meierrieks, D., \& Gries, T., (2013). "Causality between terrorism and economic growth", Journal of Peace Research, 50(1), pp. 91-104.

Melly, P., \& Darracq, V., (2013). "A New Way to Engage? French Policy in Africa from Sarkozy to Hollande", Catham House, Africa 2013/01, London.

Mirza, D., \& Verdier, T., (2008), "International trade, security and transnational terrorism: Theory and a survey of empirics", Journal of Comparative Economics, 36(2), pp. 179-194.

Nitsch, V., \& Schumacher, D., (2004), “Terrorism and international trade: an empirical investigation”, European Journal of Political Economy, 20(2), pp. 423-433.

Öcal, N., and Yildirim, J., (2010). "Regional effects of terrorism on economic growth in Turkey: A geographically weighted regression approach", Journal of Peace Research, 47(4), pp. 477-489.

Okada, K., \& Samreth, S.,(2012), "The effect of foreign aid on corruption: A quantile regression approach", Economic Letters, 115(2), pp. 240-243.

Oreopoulos, P., \& Salvanes, K. G., (2009). "How Large are Returns to Schooling? Hint: Money Isn't Everything.", NBER Working Paper No. 15339.

Piazza, J. A., (2006). "Rooted in Poverty?: Terrorism, Poor Economic Development, and Social Cleavages”, Terrorism and Political Violence, 18(1), pp. 159-177.

Piazza, J. A., (2011), "The illicit drug trade, counternarcotics strategies and terrorism", Public Choice, 149(3-4), pp. 297-314.

Piazza, J. A., (2012), "The Opium Trade and Patterns of Terrorism in the Provinces of Afghanistan: An Empirical Analysis”, Terrorism and Political Violence, 24(2), pp. 213-234.

Price, G. N., \& Elu, J. U., (2016), "Global Warming And Cross-State Islamist Terrorism In Nigeria”, Department of Economics, Morehouse College, Atlanta GA.

Richardson, M., (2004), "A Time Bomb for Global Trade: Maritime-related Terrorism in an Age of Weapons of Mass Destruction”, Maritime Studies, Volume 2004 (134), pp. 1-8.

Rodrik, D., (2008). "The Real Exchange Rate and Economic Growth", Harvard University, http://www.hks.harvard.edu/fs/drodrik/Research\%20papers/RER\%20and\%20growth.pdf (Accessed: 29/04/2015).

Rudra, N., \& Jensen, N. M., (2011). "Globalisation and the Politics of Natural Resources", Comparative Political Studies, 44(6), pp. 639-661.

Shahbaz, M., Shahbaz, S., M., Nasir, M. M., \& Edward, W. M., (2013). "An analysis of a causal relationship between economic growth and terrorism in Pakistan", Economic Modelling, 35(September), pp. 21-29. 
Shahzad, S. J. H., Zakaria, M., Rehman, M. U., Ahmed, T., \& Fida, B. A., (2015)

"Relationship Between FDI, Terrorism and Economic Growth in Pakistan: Pre and Post 9/11 Analysis", Social Indicators Research, (March, 2015)

http://link.springer.com/article/10.1007\%2Fs11205-015-0950-5

Singh, P., (2001). "Punjab Terrorism: Truth Still Uncovered", Economic and Political Weekly, 36 (40), pp. 3829-3831.

Singh, P., (2007). "The Political Economy of the Cycles of Violence and Non-violence in the Sikh Struggle for Identity and Political Power: implications for Indian federalism", Third World Quarterly, 28(3), pp. 555-570.

Thomas, K.W., (1992). Conflict and negotiation processes in organisations. In: Dunnette, M.D. and L.M. Hough eds. Handbook of industrial and organisational psychology. Palo Alto, CA, Consulting Psychologists Press. pp. 651-717.

Volkema, R. J., \& Bergmann, T. J., (1995). "Conflict styles as indicators of behavioural patterns in interpersonal conflicts". The Journal of Social Psychology, 135 (1), pp. 5-15.

World Bank (2015). "World Development Indicators', World Bank Publications http://www.gopa.de/fr/news/world-bank-release-world-development-indicators-2015 (Accessed: 25/04/2015). 